\title{
Front Matter: Volume 6644
}

, "Front Matter: Volume 6644," Proc. SPIE 6644, Optical Trapping and Optical Micromanipulation IV, 664401 (18 September 2007); doi: 10.1117/12.771459

SPIE Event: NanoScience + Engineering, 2007, San Diego, California, United States 


\section{PROCEEDINGS OF SPIE}

\section{Optical Trapping and Optical Micromanipulation IV}

Kishan Dholakia

Gabriel C. Spalding

Editors

26-29 August 2007

San Diego, California, USA

Sponsored by

SPIE 
The papers included in this volume were part of the technical conference cited on the cover and title page. Papers were selected and subject to review by the editors and conference program committee. Some conference presentations may not be available for publication. The papers published in these proceedings reflect the work and thoughts of the authors and are published herein as submitted. The publisher is not responsible for the validity of the information or for any outcomes resulting from reliance thereon.

Please use the following format to cite material from this book:

Author(s), "Title of Paper," in Optical Trapping and Optical Micromanipulation IV, edited by Kishan Dholakia, Gabriel C. Spalding, Proceedings of SPIE Vol. 6644 (SPIE, Bellingham, WA, 2007) Article CID Number.

ISSN 0277-786X

ISBN 9780819467928

Published by

SPIE

P.O. Box 10, Bellingham, Washington $98227-0010$ USA

Telephone +1 3606763290 (Pacific Time) · Fax +1 3606471445

SPIE.org

Copyright (c) 2007, Society of Photo-Optical Instrumentation Engineers

Copying of material in this book for internal or personal use, or for the internal or personal use of specific clients, beyond the fair use provisions granted by the U.S. Copyright Law is authorized by SPIE subject to payment of copying fees. The Transactional Reporting Service base fee for this volume is $\$ 18.00$ per article (or portion thereof), which should be paid directly to the Copyright Clearance Center (CCC), 222 Rosewood Drive, Danvers, MA 01923. Payment may also be made electronically through CCC Online at copyright.com. Other copying for republication, resale, advertising or promotion, or any form of systematic or multiple reproduction of any material in this book is prohibited except with permission in writing from the publisher. The CCC fee code is $0277-786 \mathrm{X} / 07 / \$ 18.00$.

Printed in the United States of America.

Publication of record for individual papers is online in the SPIE Digital Library.

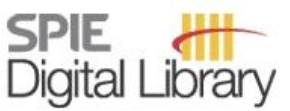

SPIEDigitalLibrary.org

Paper Numbering: Proceedings of SPIE follow an e-First publication model, with papers published first online and then in print and on CD-ROM. Papers are published as they are submitted and meet publication criteria. A unique, consistent, permanent citation identifier (CID) number is assigned to each article at the time of the first publication. Utilization of CIDs allows articles to be fully citable as soon they are published online, and connects the same identifier to all online, print, and electronic versions of the publication. SPIE uses a six-digit CID article numbering system in which:

- The first four digits correspond to the SPIE volume number.

- The last two digits indicate publication order within the volume using a Base 36 numbering system employing both numerals and letters. These two-number sets start with 00, 01, 02, 03, 04, 05, $06,07,08,09,0 \mathrm{~A}, 0 \mathrm{~B} \ldots \mathrm{OZ}$, followed by $10-1 \mathrm{Z}, 20-2 \mathrm{Z}$, etc.

The CID number appears on each page of the manuscript. The complete citation is used on the first page, and an abbreviated version on subsequent pages. Numbers in the index correspond to the last two digits of the six-digit CID number. 


\section{Contents}

ix Conference Committee

\section{SESSION 1 OPTICAL TRAPS AND DNA}

664403 Stretching sub-micron DNA fragments with optical tweezers (Invited Paper) [6644-02]

Y.-F. Chen, G. A. Blab, J.-C. Meiners, Univ. of Michigan (USA)

664404 Studies of viral DNA packaging motors with optical tweezers: a comparison of motor function in bacteriophages $\varphi 29, \lambda$, and T4 [6644-03]

D. E. Smith, D. N. Fuller, D. M. Raymer, P. Rickgaver, Univ. of California, San Diego (USA);

S. Grimes, P. J. Jardine, D. L. Anderson, Univ. of Minnesota (USA); C. E. Catalano, Univ. of Washington (USA); V. Kottadiel, V. B. Rao, Catholic Univ. of America (USA)

664405 DNA binding proteins that alter nucleic acid flexibility [6644-04]

M. McCauley, Northeastern Univ. (USA); P. R. Hardwidge, L. J. Maher III, Mayo Clinic College of Medicine (USA); M. C. Williams, Northeastern Univ. (USA)

664406 High-resolution single-molecule optical trapping measurements of transcription with basepair accuracy: instrumentation and methods (Invited Paper) [6644-05]

W. J. Greenleaf, K. L. Frieda, E. A. Abbondanzieri, Stanford Univ. (USA); M. T. Woodside, Univ. of Alberta (Canada) and National Research Council of Canada (Canada); S. M. Block,

Stanford Univ. (USA)

\section{SESSION 2 STATISTICAL MECHANICS OF SMALL SYSTEMS}

664408 The Kerr effect produced by optical trapping of nanoparticles in aqueous suspensions [6644-08]

J. Junio, E. Blanton, H. D. Ou-Yang, Lehigh Univ. (USA)

\section{SESSION $3 \quad$ SINGLE MOLECULE STUDIES}

6644 OB Optical trapping studies of acto-myosin motor proteins (Invited Paper) [6644-10]

R. E. Farrow, P. B. Rosenthal, G. I. Mashanov, A. A. Holder, J. E. Molloy, MRC National Institute for Medical Research (United Kingdom)

6644 OC Direct measurement of the intermolecular forces confining a single entangled DNA molecule [6644-11]

R. M. Robertson, D. E. Smith, Univ. of California, San Diego (USA)

6644 OD Hydrosomes: optically trapped water droplets as nano-containers (Invited Paper) [6644-12] K. Helmerson, J. E. Reiner, A. M. Crawford, A. M. Jofre, R. B. Kishore, L. S. Goldner, J. Tang, M. E. Greene, National Institute of Standards and Technology (USA); M. Gilson, Univ. of Maryland (USA) 
6644 OE Hydrosomes: femtoliter containers for fluorescence spectroscopy studies [6644-13] A. M. Jofre, J. Tang, M. E. Greene, G. M. Lowman, National Institute of Standards and Technology (USA); N. Hodas, California Institute of Technology (USA); R. Kishore,

K. Helmerson, L. S. Goldner, National Institute of Standards and Technology (USA)

\section{SESSION 4 TRIGGERED EVENTS IN BIOLOGICAL SYSTEMS}

$6644 \mathrm{OH}$ Optical tweezers and multiphoton microscopies integrated photonic tool for mechanical and biochemical cell processes studies [6644-16]

A. A. de Thomaz, W. M. Faustino, State Univ. of Campinas (Brazil); A. Fontes, Federal Univ. of Pernambuco (Brazil); H. P. Fernandes, M. d. L. Barjas-Castro, K. Metze, S. Giorgio,

L. C. Barbosa, C. L. Cesar, State Univ. of Campinas (Brazil)

$66440 \mathrm{~J}$ Laser microbeams and optical tweezers to study DNA repair and ageing [6644-18]

P. Grigaravicius, S. Monajembashi, Fritz Lipmann Institute (Germany); G. Pilarczyk, Univ. of

Giessen (Germany); A. Rapp, Fritz Lipmann Institute (Germany) and Univ. of Oxford (United Kingdom); K. O. Greulich, Fritz Lipmann Institute (Germany)

\section{SESSION 5 OPTICAL MEASUREMENTS OF VISCOSITY/RHEOLOGY}

$6644 \mathrm{OL}$ Linear and nonlinear laser-trapping microrheology (Invited Paper) [6644-20]

C. F. Schmidt, Georg-August-Univ. (Germany); D. Mizuno, Kyushu Univ. (Japan)

$66440 \mathrm{M}$ Studying red blood cell agglutination by measuring membrane viscosity with optical tweezers [6644-21]

H. P. Fernandes, Univ. Estadual de Campinas (Brazil); A. Fontes, Univ. Federal de Pernambuco (Brazil); A. A. de Thomaz, L. C. Barbosa, M. L. Barjas-Castro, C. L. Cesar, Univ. Estadual de Campinas (Brazil)

664400 Microrheology of microlitre samples: probed with rotating optical tweezers [6644-23] S. J. W. Parkin, G. Knöner, T. A. Nieminen, N. R. Heckenberg, H. Rubinsztein-Dunlop, The Univ. of Queensland (Australia)

\section{SESSION 6 TOWARDS LAB-ON-A-CHIP}

6644 OP Micro-optics for optical trapping in microfluidics [6644-24]

F. Merenda, J. Rohner, E. Lamothe, P. Pascoal, J.-M. Fournier, R.-P. Salathé, Ecole Polytechnique Fédérale de Lausanne (Switzerland)

$6644 \mathrm{OR}$ Force measurement and optical assisted particle separation in an optical standing wave [6644-26]

W. Mu, Z. Li, L. Luan, Northwestern Univ. (USA); P. West, Michigan Technological Univ. (USA);

H. Kyriazes, Niles North High School (USA); G. C. Spalding, Illinois Wesleyan Univ. (USA);

G. Wang, Indiana Univ.-Purdue Univ., Fort Wayne (USA); A. Feinerman, Univ. of Illinois at

Chicago (USA); J. B. Ketterson, Northwestern Univ. (USA)

6644 OS Transport and separation of microspheres with lensless imaging technique [6644-27]

Y. Y. Sun, J. Bu, L. S. Ong, X.-C. Yuan, Nanyang Technological Univ. (Singapore) 
6644 OU Optical microrotors: theory, design and fabrication [6644-29]

V. L. Y. Loke, T. Asavei, T. A. Nieminen, N. R. Heckenberg, H. Rubinsztein-Dunlop, The Univ. of Queensland (Australia)

\section{SESSION 7 PHUN WITH PHASE}

6644 OX Encoding arbitrary grey-level optical landscapes for trapping and manipulation using GPC (Invited Paper) [6644-32]

C. A. Alonzo, P. J. Rodrigo, D. Palima, J. Glückstad, Technical Univ. of Denmark (Denmark)

6644 OY Optical coherence measurements of vortex light fields using optically manipulated microapertures [6644-33]

W. M. Lee, K. Dholakia, Univ. of St. Andrews (United Kingdom)

$66440 Z$ Rotating matter with optical and acoustical wavefields: new aspects of angular momentum transfer (Invited Paper) [6644-34]

K. Volke-Sepulveda, A. Vásquez-Arzola, N. Hernández-Candia, R. Jáuregui,

A. Orozco-Santillán, Univ. Nacional Autónoma de México (Mexico); V. Arrizón, Instituto Nacional de Astrofísica (Mexico)

664410 Vortical laser tweezers with predetermined intensity structure [6644-35]

K. N. Afanasiev, E. G. Abramochkin, A. V. Korobtsov, S. P. Kotova, N. N. Losevsky,

E. V. Razueva, V. G. Volostnikov, P.N. Lebedev Physical Institute (Russia)

\section{SESSION 8 BASIC SCIENCE}

664411 All-optical manipulation of neutral atomic ensembles [6644-36]

W. T. Hill III, N. Chattrapiban, I. V. Arakelyan, S. Mitra, Y. Song, Univ. of Maryland, College Park (USA)

664413 Momentum of the electromagnetic field in transparent dielectric media [6644-38]

M. Mansuripur, College of Optical Sciences, The Univ. of Arizona (USA)

\section{SESSION 9 OPTICAL BINDING}

664417 Layer-by-layer optical assembly of colloidal particles [6644-43]

G. Wang, Indiana Univ.-Purdue Univ., Fort Wayne (USA)

\section{SESSION 10 PLASMONICS/NANO}

6644 1B Optical trapping of nanoshells [6644-49]

B. C. Hester, A. Crawford, R. B. Kishore, K. Helmerson, National Institute of Standards and Technology (USA); N. J. Halas, C. Levin, Rice Univ. (USA)

6644 1C Plasmon-enhanced optical trapping of individual metal nanorods (Invited Paper) [6644-51] M. Pelton, Argonne National Lab. (USA); M. Liu, K. C. Toussaint, Jr., H. Y. Kim, G. Smith, J. Pesic, P. Guyot-Sionnest, Univ. of Chicago (USA); N. F. Scherer, Argonne National Lab. (USA) and Univ. of Chicago (USA) 
664411 Studies of droplet manipulation in optical traps (Invited Paper) [6644-55]

D. McGloin, Univ. of Dundee (United Kingdom); D. R. Burnham, M. D. Summers, D. R. Rudd, A. Shahvisi, Univ. of Dundee (United Kingdom) and Univ. of St. Andrews (United Kingdom); N. Dewar, Univ. of Dundee (United Kingdom)

$66441 \mathrm{~J} \quad$ Parametric excitation of optically trapped aerosols (Invited Paper) [6644-56]

R. Di Leonardo, G. Ruocco, INFM CRS SOFT, Univ. di Roma (Italy); J. Leach, M. J. Padgett, Univ. of Glasgow (United Kingdom); A. J. Wright, J. M. Girkin, Univ. of Strathclyde (United Kingdom); D. R. Burnham, D. McGloin, Univ. of St. Andrews (United Kingdom) and Univ. of Dundee (United Kingdom)

\section{SESSION 12 OPTICAL TRAPS FOR NOVEL SENSORS}

$66441 \mathrm{~K}$ Circular motion control of an optically trapped microprobe for nano-position sensing [6644-57]

Y. Nagasaka, Y. Takaya, T. Hayashi, Osaka Univ. (Japan)

6644 IL Micro-manipulation using combined optical tweezers and atomic force microscope [6644-58]

H. Sehgal, T. De, lowa State Univ. (USA); S. Nettikadan, Bioforce Nanosciences, Inc. (USA); M. V. Salapaka, lowa State Univ. (USA)

6644 IM Cavitation induced by continuous wave lasers [6644-59]

J. C. Ramirez-San-Juan, E. Rodriguez-Aboytes, N. Korneev, O. Baldovinos-Pantaleon, Instituto Nacional de Astrofísica, Óptica y Electrónica (Mexico); R. Chiu-Zarate, G. Gutiérrez-Juárez, Univ. de Guanajuato (Mexico); R. Dominguez-Cruz, Univ. Autónoma de Tamaulipas (Mexico); R. Ramos-García, Instituto Nacional de Astrofísica, Óptica y Electrónica (Mexico)

\section{SESSION 13 OPTICS OF OPTICAL TRAP SYSTEMS}

$66441 Q \quad$ Vision feedback driven automated assembly of photopolymerized structures by parallel optical trapping and manipulation [6644-63]

J. S. Dam, I. R. Perch-Nielsen, P. J. Rodrigo, Technical Univ. of Denmark (Denmark);

L. Kelemen, Institute of Biophysics. (Hungary); C. A. Alonzo, Technical Univ. of Denmark (Denmark); P. Ormos, Institute of Biophysics (Hungary); J. Glückstad, Technical Univ. of Denmark (Denmark)

\section{SESSION 14 OPTICAL CONTROL FOR BIOLOGICAL STUDIES}

$66441 \mathrm{U}$ Preparative separations using optical chromatography [6644-67]

A. Terray, J. Arnold, Naval Research Lab. (USA); S. D. Sundbeck, American Society for Engineering Education, Postdoctoral Fellow (USA); T. A. Leski, National Research Council, Naval Research Lab., Postdoctoral Research Associate (USA); S. J. Hart, Naval Research Lab. (USA) 
6644 IW Uncoiling mechanism of Klebsiella pneumoniae type 3 pili measured by using optical tweezers [6644-69]

F.-J. Chen, C.-H. Chan, National Chiao Tung Univ. (Taiwan); K.-L. Liu, National Tsing Hua Univ. (Taiwan); Y.-J. Huang, H.-L. Peng, National Chiao Tung Univ. (Taiwan); H.-Y. Chang, T.-R. Yew, National Tsing Hua Univ. (Taiwan); K. Y. Hsu, L. Hsu, National Chiao Tung Univ. (Taiwan)

$66441 \mathrm{X}$ Stable manipulating of nanowires by line optical tweezers with haptic feedback [6644-70] S.-W. Lee, T. Lee, Y.-G. Lee, Gwangju Institute of Science and Technology (South Korea)

6644 IY Real-time control of optical tweezers [6644-72]

A. E. Wallin, H. Ojala, A. Korsbäck, E. Haeggström, R. Tuma, Univ. of Helsinki (Finland)

\section{POSTER SESSION}

664420 Extending the lateral trapping force of optical tweezers [6644-74]

A. C. Richardson, The Niels Bohr Institute (Denmark); S. N. S. Reihani, The Niels Bohr Institute (Denmark) and Institute of Advanced Studies in Basic Sciences (Iran); L. B. Oddershede, The Niels Bohr Institute (Denmark)

664421 Improving optical trapping in the axial direction and a continuous change of the optimal trapping depth [6644-75]

S. N. S. Reihani, Institute for Advanced Studies in Basic Sciences (Iran) and Niels Bohr Institute (Denmark); L. B. Oddershede, Niels Bohr Institute (Denmark)

664426 Laser cooling in flame synthesis of nanoparticles [6644-81]

$X$. Liu, Rutgers, The State Univ. of New Jersey (USA)

664427 Flow-assisted collection of DNA molecules on silica beads [6644-82]

N. Korneev, R. Ramos-García, J. C. Ramirez-San-Juan, E. Rodriguez-Aboytes, Instituto Nacional de Astrofísica, Óptica y Electrónica (Mexico); M. Cárdenas-García, BUAP (Mexico)

Author Index 
Downloaded From: https://www.spiedigitallibrary.org/conference-proceedings-of-spie on 26 Apr 2023

Terms of Use: https://www.spiedigitallibrary.org/terms-of-use 


\title{
Conference Committee
}

\author{
Symposium Chairs
}

David L. Andrews, University of East Anglia Norwich (United Kingdom)

James G. Grote, Air Force Research Laboratory (USA)

Kevin J. Liddane, Oerlikon Optics USA, Inc. (USA)

Conference Chairs

Kishan Dholakia, University of St. Andrews (United Kingdom)

Gabriel C. Spalding, Illinois Wesleyan University (USA)

Program Committee

Elliot L. Botvinick, Beckman Laser Institute (USA)

Carlos L. César, Universidade Estadual de Campinas (Brazil)

Arthur E. T. Chiou, National Yang-Ming University (Taiwan)

Eric R. Dufresne, Yale University (USA)

Jesper Glückstad, Risø National Laboratory (Denmark)

Min Gu, Swinburne University of Technology (Australia)

Philippe J. Marchand, Celula, Inc. (USA)

Jens-Christian D. Meiners, University of Michigan (USA)

Lene B. Oddershede, Niels Bohr Institute (Denmark)

H. D. Ou-Yang, Lehigh University (USA)

Rubén Ramos-García, Instituto Nacional de Astrofísica, Óptica y

Electrónica (Mexico)

Alexander Rohrbach, Albert-Ludwigs-Universität Freiburg (Germany)

Halina H. Rubinsztein-Dunlop, The University of Queensland (Australia)

\section{Session Chairs}

1 Optical Traps and DNA

Justin E. Molloy, National Institute for Medical Research

(United Kingdom)

2 Statistical Mechanics of Small Systems

Astrid van der Horst, Simon Fraser University (Canada)

$3 \quad$ Single Molecule Studies

Jens-Christian D. Meiners, University of Michigan (USA) 
$4 \quad$ Triggered Events in Biological Systems

Kishan Dholakia, University of St. Andrews (United Kingdom)

5 Optical Measurements of Viscosity/Rheology

Elliot L. Botvinick, Beckman Laser Institute (USA)

6 Towards Lab-on-a-Chip

Jesper Glückstad, Risø National Laboratory (Denmark)

7 Phun with Phase

Halina H. Rubinsztein-Dunlop, The University of Queensland (Australia)

8 Basic Science

Kristian Helmerson, National Institute of Standards and Technology (USA)

$9 \quad$ Optical Binding

Gabriel C. Spalding, Illinois Wesleyan University (USA)

10 Plasmonics/Nano

Carlos L. César, Universidade Estadual de Campinas (Brazil)

11 Colloid Science with Optical Traps

H. Daniel Ou-Yang, Lehigh University (USA)

12 Optical Traps for Novel Sensors

Sunil Sainis, Yale University (USA)

13 Optics of Optical Trap Systems

Rubén Ramos-García, Instituto Nacional de Astrofísica, Óptica y Electrónica (Mexico)

14 Optical Control for Biological Studies

David W. M. Marr, Colorado School of Mines (USA) 